\title{
Agroecological transition and reconfiguration of horticultural work among family farmers in Buenos Aires, Argentina
}

\author{
Gabriela Parodi ${ }^{1,2, *}$ \\ ${ }^{1}$ CEIL CONICET (Centro de Estudios e Investigaciones Laborales - Consejo Nacional de Investigaciones Científicas y Técnicas), \\ Saavedra 15 (C1083ACA), Ciudad Autónoma de Buenos Aires, Buenos Aires, Argentina \\ ${ }^{2}$ Universidad Nacional de Lanús (UNLa), 29 de Septiembre 3901 (1826), Remedios de Escalada, Lanús, Argentina
}

\begin{abstract}
In Argentina, family farmers who engage in horticultural production have recently adopted the process of agroecological transition into their work. The process involves organisations, such as the Land Workers' Union (UTT) cooperative, located in the horticultural belt in the province of Buenos Aires. The case study under analysis shows family farmers' challenges with the agroecological transition process. These challenges include the reconfiguration of horticultural work, which impacts the skills needed to perform the work; the organisation of work; and the sustainability conditions involved in introducing agroecology as a social-productive model for growing vegetables. We examine start-up and development strategies for the agroecological transition process involving farmers and State agents. Our methodology is qualitative and we rely on semi-structured interviews and observations with family farmers belonging to the UTT cooperative. This paper explores how the process of agroecological transition that family farmers in Buenos Aires implement into their horticultural work affects their production and marketing practices. The primary goal is to explain the unequal evolution of this process. This inequality is particularly evident in the decision-making processes in which farmers engage prior to implementing the agroecological transition. They must consider a host of factors influencing their capacity to innovate and diversify production and sales through short food supply chains. These factors include their land tenure conditions (i.e., be a tenant or owner of the land), their level of economic capital (i.e., their access to greenhouses), and the size of their production. They largely account for the varying speeds at which farmers in this case study implement the process of agroecological transition into their farming.
\end{abstract}

Keywords: Agroecology / transition / family farming / work / horticulture /

Résumé - Transition agroécologique et reconfiguration du travail en maraîchage chez les producteurs familiaux à Buenos Aires, Argentine. En Argentine, le processus de transition agroécologique a récemment été adopté par des agriculteurs familiaux se consacrant au maraîchage. Il concerne des organisations de producteurs situées à la périphérie de Buenos Aires, dans la ceinture maraîchère dénommée "bonaerense », notamment la coopérative de l'Union des travailleurs de la terre (UTT). L'étude de cas que nous présentons montre les défis pour ces agriculteurs en termes de reconfiguration du travail maraîcher, d'articulation des savoir-faire, d'organisation des tâches et de durabilité, lorsqu'ils adoptent l'agroécologie comme modèle socio-productif. Nous caractérisons les stratégies de départ et de développement du processus de transition agroécologique auquel participent les producteurs et les techniciens d'organismes publics, en nous appuyant sur une méthodologie qualitative basée sur des entretiens semi-structurés et des observations réalisées dans les exploitations maraîchères de la coopérative UTT. L'article examine comment l'adoption de la transition agroécologique dans le maraîchage modifie les formes d'articulation des pratiques de production et de commercialisation des légumes produits par des agriculteurs familiaux, et destinés à la consommation directe. L'objectif est d'expliquer l'évolution différenciée de ce processus chez les producteurs étudiés. Ces différences sont manifestes dans les prises de décisions des agriculteurs avant la mise en œuvre de la transition agroécologique. Les agriculteurs doivent tenir compte d'une série de variables qui conditionnent leurs

\footnotetext{
* Auteur de correspondance: gabrielaparodi6@gmail.com.
} 
capacités à innover et à diversifier la production et les ventes à travers des circuits courts de commercialisation. Ces variables incluent les conditions foncières (être propriétaire ou locataire de la terre), le niveau de capitalisation (avoir accès ou non à des serres), ainsi que les projets productifs. Elles expliquent en grande partie la plus ou moins grande rapidité avec laquelle les agriculteurs mettent en œuvre le processus de transition agroécologique dans leurs exploitations.

Mots clés : Agroécologie / transition / agriculture familiale / travail / maraîchage

\section{Introduction and framework of the study}

The horticultural belt outside of Argentina's capital city, Buenos Aires, is the subject of many studies in rural sociology, anthropology and agronomy (Benencia and Quaranta, 2009; García, 2011; Otero et al., 2013). This belt formed a century ago as part of the city's urban planning efforts of the surrounding areas occupied by houses and farms. It is one of the most important suburban areas in Argentina, and is characterised by a network of farmers of different descents who settled there over the course of history. Historically, these farmers have been of Italian, Spanish, and Portuguese descent. More recently, the population of Bolivian farmers has increased (Barsky, 2010). This region is also characterised by its high population density. There are 14.5 million inhabitants in a 18,028 square kilometer territory (INTA, 2014).

The present study focuses on family farmers - mostly of Bolivian origin - affiliated with the Land Workers' Union (UTT) cooperative. They are primarily located in the Metropolitan Area of Buenos Aires (AMBA), which is comprised of the city of Buenos Aires, as well as 39 urban and peri-urban districts within the province of Buenos Aires. The specific area under study within this region is called Greater La Plata. It is located in the southern part of AMBA, in the Berazategui district (Fig. 1), which is one of 12 districts comprising the second urban belt. This second belt extends up to $40-50 \mathrm{~km}$ away from the capital city. The largest concentration of vegetable farms is located within this southern section of AMBA. Given the dense population and high demand for produce, farmers sell the greatest volume of their vegetables through local and regional market hubs and supermarket chains in AMBA. As a result, this region of the country is known for its abundant supply of fresh vegetables.

Recently, this horticultural production has experienced a gradual shift in the technology use. For decades, it relied on agricultural inputs commonly referred to as the "conventional technology package". These inputs include hybrid seeds, fertilisers, and fungicides. This technology is now being replaced by agroecological farming practices, which are part of the systematic approach to agroecology (Altieri, 1995; Gliessman, 2002; Sevilla Guzmán and Soler Montiel, 2009). In agroecology, land tenure conditions become the main factor influencing vegetable farmers. This transitional process-taking place in farming practices is known as "agroecological transition". It is a process of moving from conventional farming systems to agroecologically-based systems. The latter involve not only technical and ecological elements, but also the sociocultural and economic aspects of farmers, their families, and the community at large (Marasas et al., 2012). As Marasas states, "production is closely related to the environmental conditions of each agricultural ecosystem and should adapt to this reality, but it is in turn deeply committed to, and conditioned by, cultural and organisational processes" (2012). In the process of agroecological transition adopted by farmers in this study, a marketing and sales strategy based on direct sales to consumers or retailers without intermediaries plays a key role. This strategy is part of a food production-distributionconsumption configuration commonly known as a "short food supply chain".

It is important to note that the towns of Abasto, El Pato, Lisandro Olmos, and Estancia Chica, where farmers in AMBA began the agroecological transition process, are not immune to the land development happening in the area. Within this context, investment groups that build gated communities exert strong pressure in order to obtain land for real estate. Depending on the area where family farms are located, this phenomenon can make gaining access to affordable land difficult. This issue of land tenure affects the socio-productive and commercial strategies employed by family farmers in this study.

\subsection{Factors affecting socio-economic mobility paths}

One characteristic defining the social and economic mobility paths of farmers in this case study is what Benencia has conceptualised as "the Bolivian horticultural ladder" (Benencia and Quaranta, 2009). According to Benencia, the migrant enters the country as a farm worker, i.e., a salaried employee. Later, he advances to the position of sharecropper (García, 2014; García et al., 2015). Finally, he becomes a tenant farmer or, sometimes, a farm owner. How this status of tenant or owner affects farmers' socioeconomic mobility is a key variable under study in the present analysis. This status is important to study because it helps to explain the variation in farmers' decision-making processes regarding the agroecological transition process. These decisions depend on a farmer's budget, as well as his profit expectations for selling his crops in short food supply chains.

After examining farmers' socioeconomic mobility, we focus on the role of commercial activity in farmers' development. As Benencia and Quaranta emphasise, the 2000-2001 economic crisis in Argentina had a profound impact on the horticultural production by introducing the sales stage (2009). With the recent development of the direct sale of agroecologically-grown vegetables in short food supply chains, we analyse how this change creates new work dynamics for farmers in our case study (Dubuisson-Quellier and Lamine, 2004; Dubuisson-Quellier and Le Velly, 2008; Le Velly and Paturel, 2013).

\subsection{Methodology}

In the initial phase of our research, we aimed to study the impact of the process of agroecological transition on the 


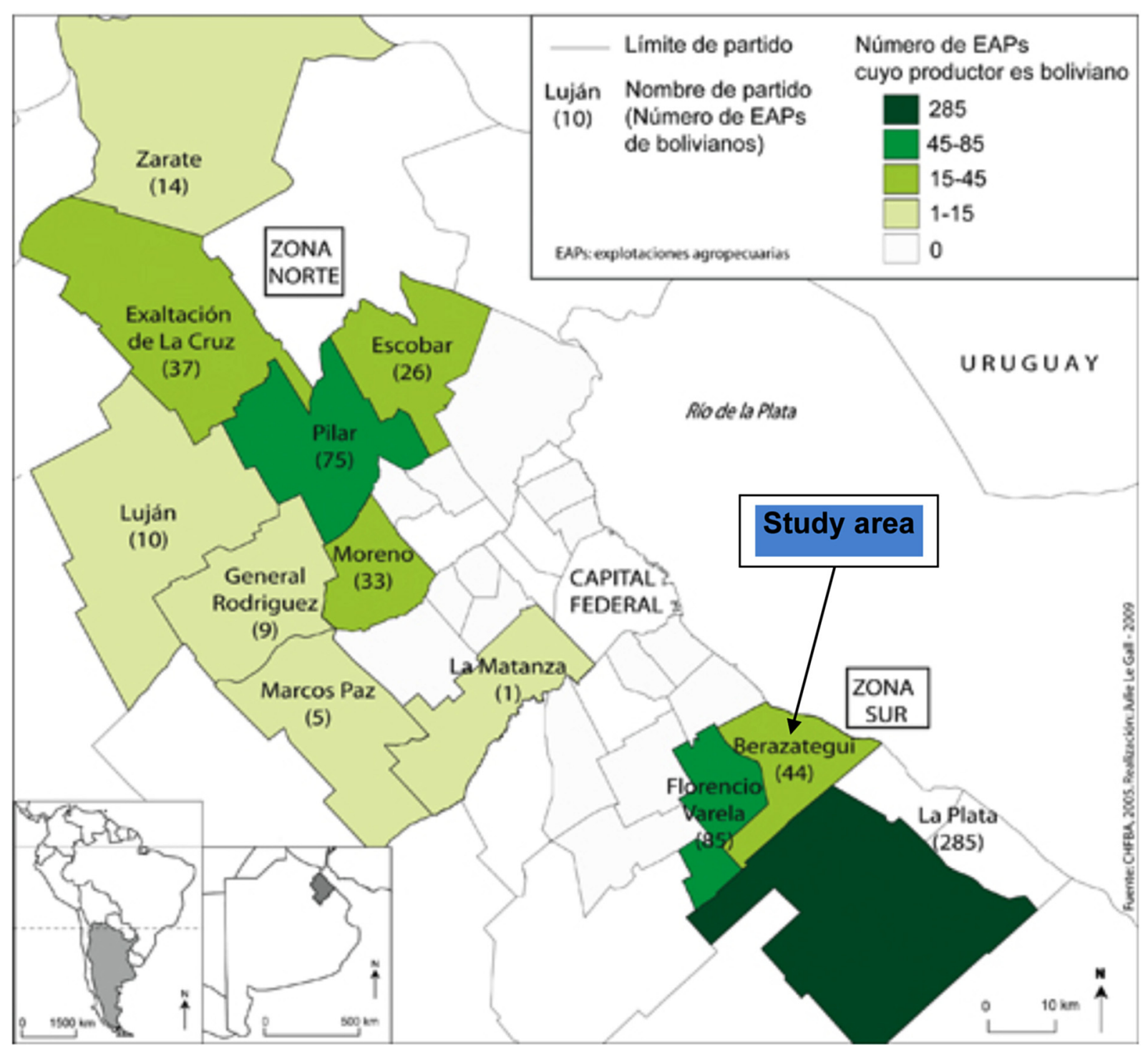

Fig. 1. The study area, in Berazategui district. Source: Le Gall and García, 2010.

Fig. 1. La zone d'étude, dans le district de Berazategui.

configuration of agricultural work. Specifically, we sought to understand how this process affects the organisation and adaptation of techniques governing farming production and marketing decisions (Amílcar Herrera Project 2015, Universidad Nacional de Lanús).

The independent variables in our study come from the extant literature on rural social studies. They include farmers' land tenure conditions, their level of economic capital (i.e., their access to a greenhouse as a form of farming technology), and the size of their production (Benencia et al., 1992; García, 2011; Otero et al., 2011). Our study sample is comprised primarily of tenant farmers who cultivate vegetables in either a field/plot or a greenhouse. Additionally, few possess capital goods such as tractors or pickup trucks for crop distribution to markets. Their highest production costs are seeds and the conventional technology package (i.e., agrochemical inputs) that they seek to fully replace with homemade bio-based inputs. It is also noteworthy that farm work for these farmers is a family affair. In other words, the farmer and his family, primarily his wife and children, perform the labour without relying on hired salaried workers. That being said, those who cultivate flowers in addition to vegetables turn to other family members, such as siblings, cousins, and in-laws, for extra help during certain seasonal cycles.

In terms of our methodology, we participated in observations at family farms by attending technical trainings, vegetable preparation and planting seminars. We also observed at universities, consumers associations, meetings between farmers and consumers, markets selling sacks of farmers' agroecologically-grown vegetables, and workshops held by the UTT cooperative involving technicians, farmers, and consumers. Another primary source of data were semistructured interviews with 10 farmers and 7 state technicians from Pro-Huerta and Cambio Rural, which are part of the National Institute for Agricultural Technology (INTA), and from the Department for Family Farming (SAF). The state technicians are responsible for running transfer and training programs and workshops for farmers. They also assist farmers 
with the implementation of agroecological farming practices and business strategies.

\subsection{The case study and its beginnings in the agroecological transition process}

When members of the UTT cooperative began the agroecological transition process, the organisation included 2,000 families divided into 35 "base" groups. These groups were created in order to establish social organisation and structure in meetings. The cooperative's territory covers districts in Greater La Plata, with its main headquarters located in the towns of Abasto and San Vicente. However, it also includes towns outside of AMBA, including Mar del Plata, Escobar, Zárate, Mercedes, Suipacha, and Luján. The cooperative's identity as an organisation with a strong ideological-political nature based on popular economic rights reflects that of union-like, non-partisan social movements, such as the Confederation of Popular Economy Workers (CTEP), to which its members adhere. According to its members, the cooperative's social commitment is part of a "social change and popular liberation project". The cooperative aims to address the crop production aspect of farmers' work through "alternative farming based on the agroecological and sustainable model". Additionally, it supports a marketing model based on a direct producer-consumer relationship, as well as access to popular health care.

In accordance with these principles, the cooperative engaged in an agroecological transition process for vegetable production using a device called the "System for the Healthy Production of Healthy Vegetables" (SPSVS). SAF technicians designed the device and the Argentine Ministry of Agriculture, Livestock and Fishery funded it. The device included a tool kit comprised of an irrigation system, saplings, fertiliser, and equipment for plot mechanisation. Farmers implemented the device's "healthy production units" in a plot, entire field, or greenhouse, using the tools provided. Additionally, farmers who utilized this device were offered training sessions on how to replace conventional farming practices with non-conventional ones, including plant or mulch cover; bio-based inputs; and homemade substances for eradicating pests and diseases. INTA employees, who were mainly agronomists, led these trainings.

The two sites for vegetable cultivation, the field and the greenhouse, reflect the different socio-productive conditions of the farming structure and the amount of capital farmers have. Since most farmers in our study are not farm owners, this determines the farming system they implement.

\section{Dynamics of the agroecological transition socio-productive integration process}

\subsection{The land issue}

On average, farmers belonging to the UTT lease 1.5 hectares per unit of production. Rent represents farmers' largest production cost and directly affects farming strategies. Thus, only those farmers with a certain amount of capital can cultivate crops in a greenhouse. The advantages of this technique include growing crops out of season, increased production, higher quality crops, earlier maturity, and less susceptibility to adverse weather conditions (Benencia et al., 1992).

Farmers who utilized the SAF device introduced agroecological transition plots measuring $1 / 8$ hectare per production unit in a field. While this area was small, these initial plots served as control plots to help farmers become familiar with agroecological farming and management. Over time, their uncertainty regarding the production yield under agroecological conditions declined. However, abandoning the belief that agrochemicals and industrial fertilisers were necessary for efficiency, and replacing these techniques with manure and bio-based inputs, was not easy. It also required that the farmer become familiar with these different products and applications.

Another challenge farmers faced in this transitional process was the diversification of crop varieties. In conventional farming, farmers produced seedlings using agrochemicals and sowing substrates purchased from input suppliers. Now, they had to rely on local seeds and engage in seedbed cultivation, selection, manipulation, transplanting, and seed stocking. This phenomenon illustrates the sociotechnical changes in farming practices associated with sustainability (Barbier and Goulet, 2013).

Farmers do not uniformly nor automatically adopt the practices and techniques associated with the agroecological transition process. Land tenure conditions, which are tied to the farmer's status as either a tenant or owner, impact the decisions a farmer makes regarding the transition to agroecological farming. For example, after the first production cycles in the agroecological transition process, a farm owner, driven by the high yield and growing demand for agroecological products, will more rapidly expand the area used for agroecological farming. He will also diversify crop varieties and supplement field cultivation with greenhouse cultivation. In contrast, a tenant farmer, who finds himself in a more vulnerable economic situation than the farm owner, will initially be more cautious and take longer to transition his leased farmland to agroecological farming. In sum, the adoption of agroecological farming practices by farmers varies according to their land tenure status as either farm owners or tenant farmers.

\subsection{Use of the greenhouse and the production project}

The greenhouse is a prime example of the technological innovations from the Green Revolution. The Green Revolution marks an important period in the history of agriculture. It was a time of great modernisation of specific technologies and the expansion and specialisation of farms in order to increase productivity and efficiency. When the greenhouse was invented as a new form of technology, it simultaneously introduced several variables affecting farming. For example, farmers now had to consider the timing of land preparation and planting cycles, since they vary between the field and greenhouse. Additionally, greenhouses require more complex organisational engineering, mainly because activities are no longer based on seasonality and tasks necessitate specialization (Otero et al., 2011).

Within the agroecological system, greenhouse use again awakens the debate around natural seasonal production cycles. Farmers and consumers who critique this technology utter 
statements such as, "Why do you want tomatoes in winter when it is not the right time?" and "we must produce and use only seasonal vegetables". Critics also cite the cost in time required for relearning about greenhouse management and cultivation tasks as part of the agroecological transition process. Often, the agronomist who trains the farmer prefers to start the agroecological transition process in the field. He does this because, especially in the first stages of the transition, the goal is to convince the farmer of the advantages of this system before investing in a greenhouse.

Farm owners, compared to tenant farmers, will be more open to innovate their farming practices with bio-based products, local seeds, and a greenhouse. As a result, they will be more willing to take greater risks concerning possible adverse outcomes in overall crop yield. This is due to the fact that unlike tenant farmers, farm owners do not have rent as one of their fixed operational costs. Rent is the greatest economic burden on the cost/income ratio for family farmers, most of whom are tenants. Since farm owners are able to more easily and quickly adopt the agroecological transition process, they assume the role of technical assistant and transmitter of knowledge within the cooperative. This process of the transfer of knowledge between farmers is known as "farmer-tofarmer".

During the agroecological transition process, family farmers must replicate the production strategy achieved in the "substeps" of acquiring capital under the conventional model (García, 2011). In other words, farmers with less capital engage in agroecological transition for leaf vegetables, including lettuce, chard, cabbage, and parsley, and do so exclusively in field plots. Farmers with greater capital, and thus, the ability to purchase seeds and bio-based inputs immediately, also implement the transition process into their cultivation of fruiting vegetables such as tomatoes, peppers, and string beans. They do this both in the field and greenhouse, while considering the variation in workload required for such projects. This variation is evident in the growing cycles; the various tasks involved, including hoeing, harvesting, and phytosanitary management; and the financial returns that depend upon the species cultivated.

\section{Commercial strategy and reorganisation of work in selling agroecological products}

Family farmers often identify marketing as a key aspect of their work to redefine in socioeconomic sustainability strategies. Recently, UTT farmers have been able to diversify their traditional marketing and sales channels that relied primarily on intermediaries (Dubuisson-Quellier and Le Velly, 2008). The principle aim is to reduce the involvement of intermediaries and avoid the disadvantages of selling through long circuits, where the price is set by the consignee who buys and resells crops to retailers, or by the intermediary who visits the farm, purchases the products directly from the farmers, and resells them at market hubs (Souza Casadinho, 2014; Seba et al., 2014). Now, these farmers are participating increasingly in short food supply chains.

The sale of agroecologically-grown vegetables in short food supply chains occurs in various spaces, including neighbourhood fairs, town squares, local associations, and university campuses. Additionally, the direct sale of sacks of agroecologically-grown vegetables to organised consumer networks, such as El Instituto para la Producción Popular, La Yumba, and Nuevo Encuentro, has grown due to market restructuring and increased demand. This phenomenon had its greatest impact on the 20UTT farmers who began the agroecological transition process in 2014. They quickly became overwhelmed by the growing demand for these vegetable sacks, which went from being between 150 and 200 every 15 days to twice as many within a few months. One of the farm owners explained this increase and the change it implied in the logistics and organisation of work in order to satisfy the growing demand. For example, it led to the cooperative establishing Colonia Integral de Abastecimiento Urbano 20 de Abril Dario Santillán in Luján, an area where 65 families settled for the purpose, among others, of increasing their supply capacity and production volumes for agroecologically-grown vegetables to be sold directly to consumers and retailers in short food supply chains.

The popularity of these agroecologically-grown vegetable sacks has had great impact on farmers' work, not only in terms of producing and commercializing their crops, but also in the organisation of labour (Aubry et al., 2011). For example, the role of the farmer becomes that of technical-business manager, work organiser, and sensitive worker (Dedieu and Servière, 2012). This is because the task of assembling the vegetable sacks affects the coordination and division of labour on farms and, therefore, demonstrates individual farms' capacities and diversity.

Each of these sacks includes 8 varieties of seasonal vegetables. Since the vast majority of farmers traditionally grew a monoculture of leaf vegetables under the conventional farming system, they have to partner with each other in order to ensure that each sack contains these vegetable varieties cultivated using the newly implemented agroecological farming practices. Sack preparation also proves challenging for farmers from a post-cultivation standpoint, as they are accustomed to filling crates or boxes with solely one product to be delivered to the intermediary. Now, they must consider the varying weights of different vegetable varieties, as well as their fragility, when packing them.

In addition to collaborating with other farmers from the cooperative in order to produce these vegetable sacks, farmers turn to extended family members for help. For example, relatives from Bolivia and parts of the Northwest, where they engage in seasonal farming such as the sugarcane harvest, temporarily relocate to AMBA, particularly in the spring and summer months. Since farmers do not hire salaried non-family workers, this type of farming is conceptualised as "family farming" for analysis purposes (Nogueira, 2013).

The previously described new business practices have redefined how farmers value their crops as they become direct sellers of their own production. In the conventional market, there was an expectation that vegetables have uniform characteristics, including size, and that they be visually "attractive", "without spots", and "not yellow". Farmers accustomed to meeting these strict criteria at first find it difficult to accept arguments in favour of agroecologicallygrown crops, which include that they are healthier, have greater nutritional quality, and have better taste, colour, and smell. They must retrain themselves from perceiving spots, 
dullness, and deformity as defects that make the vegetables of lower quality.

Part of this retraining of farmers' perceptions of the physical characteristics of their crops involves commercializing their vegetable sacks in short food supply chains committed to responsible consumption practices, such as the prioritisation of organic, agroecologically-grown, and/or fairly traded products. That being said, key players in the UTT cooperative who are involved in the process of setting the sack price are opposed to segmented or "niche" consumption practices designed for consumers with greater economic means. Also, they typically update the sack price every three to four months during a meeting. This meeting is open to the public so that consumers can learn about price formation that is rooted in a popular consumption logic.

\section{Conclusions}

The reconfiguration of horticultural work through the agroecological transition process adopted by family farmers in the Metropolitan Area of Buenos Aires, who traditionally relied on conventional farming practices to supply the region's fresh vegetables, requires not only relearning farming tasks and adjusting to a new work pace; it also requires that farmers consider to what extent this new farming system proves feasible and sustainable in the long run.

Implementing the agroecological transition process leads to commercial and socio-productive innovation for family farmers. The commercial innovation can be attributed to farmers' economic success as a result of a new marketing strategy. This marketing and sales strategy entails the direct sale of agroecologically-grown vegetable sacks (i.e., sales that do not rely on intermediaries) in short food supply chains; the fixing of "fair" prices for and by both farmer and consumer; and the potential of a specialised market for these products. In terms of the socio-productive innovation, it is the result of the increasing demand for, and consumption of, agroecologicallygrown vegetables. These phenomena lead farmers to integrate more field plots into the agroecological transition process and, depending on their level of economic capital, incorporate the greenhouse in this new farming approach.

Nonetheless, it is still too early to assess the qualitative impact of this horticultural reconfiguration on the production, health, economic, commercial, and environmental factors commonly recognised as drivers for implementing the agroecological transition process (Marasas et al., 2012). This is largely the case because there exists a degree of structural informality in this reconfiguration. Family farmers themselves usually advocate for this informality, as many wish to avoid adhering to regulations. These regulations are not yet institutionally developed for agroecological farming in Argentina. Additionally, it is nearly impossible to identify specific public policies and government bodies exclusively devoted to its implementation.

\section{References}

Altieri MA. 1995. Agroecology: the science of sustainable agriculture. Boulder: Westview Press, 433 p.
Aubry C, Bressoud F, Petit C. 2011. Les circuits courts en agriculture revisitent-ils l'organisation du travail dans l'exploitation? In : Béguin P, Dedieu B, Sabourin E, eds. Le travail en agriculture : son organisation et ses valeurs face à l'innovation. Paris: L'Harmattan, pp. 19-36.

Barbier JM, Goulet F. 2013. Moins de technique, plus de nature : pour une heuristique des pratiques d'écologisation de l'agriculture. Natures Sciences Sociétés 21(2): 200-210. DOI: 10.1051/nss/ 2013094.

Barsky A. 2010. La agricultura de "cercanías" a la ciudad y los ciclos del territorio periurbano. Reflexiones sobre el caso de la Región Metropolitana de Buenos Aires. In : Svetlitza de Nemirovsky A, ed. Globalización y Agricultura Periurbana en la Argentina. Escenarios, recorridos y problemas. Buenos Aires: Serie Monografías $\mathrm{N}^{\circ} 1$ Flacso Argentina, pp. 15-29.

Benencia R, Cattaneo C, Fernández R. 1992. Consecuencias de la adopción del invernáculo en las quintas hortícolas del Área Hortícola. Buenos Aires: Documento de trabajo 35 CEILCONICET.

Benencia R, Quaranta G. 2009. Familias bolivianas en la actividad hortícola: transformaciones en sus procesos de movilidad. In : Benencia R, Quaranta G, Souza Casadinho J, eds. Cinturón hortícola de la Ciudad de Buenos Aires. Cambios sociales y productivos. Buenos Aires: Ediciones CICCUS, pp. 111-126.

Dedieu B, Servière G. 2012. Vingt ans de recherche-développement sur le travail en élevage: acquis et perspectives. In : Hostiou N, Dedieu B, Baumont R, eds. INRA Productions Animales. INRA Editions 25(2): pp. 85-100.

Dubuisson-Quellier S, Lamine C. 2004. Faire le marché autrement. L'abonnement à un panier de fruits et de légumes comme forme d'engagement politique des consommateurs. In : Chessel ME, Cochoy F, eds. Marché et politique. Autour de la consommation engagée. Sciences de la société 62. Toulouse: Presses universitaires du Mirail, pp. 144-167.

Dubuisson-Quellier S, Le Velly R. 2008. Les circuits courts entre alternative et hybridation. In: Maréchal G, ed. Les circuits courts alimentaires. Bien manger dans les territoires. Dijon: Educagri, coll. Références, pp. 105-112.

García M. 2011. Proceso de acumulación de capital en campesinos. El caso de los horticultores bolivianos de Buenos Aires (Argentina). Cuadernos de Desarrollo Rural 8(66): 47-70.

García M. 2014. Fuerza de trabajo en la horticultura de La Plata (Buenos Aires, Argentina). Razones y consecuencias de su competitividad. Trabajo y Sociedad 22: 67-85.

García M, González E, Lemmi S. 2015. Aparcería en la horticultura. Legislación necesaria - aunque insuficiente- para un acuerdo asociativo. Pilquen 18: 66-80.

Gliessman SR. 2002. Agroecología: procesos ecológicos en agricultura sostenible. Turrialba: CATIE, $359 \mathrm{p}$.

INTA. 2014. Agricultura Urbana y Periurbana en el Área Metropolitana de Buenos Aires Creación de la Estación Experimental Agropecuaria AMBA.

Le Gall J, García M. 2010. Reestructuraciones de las periferias hortícolas de Buenos Aires y modelos espaciales ¿Un archipiélago verde? Echo Géo, 11, [online]. URL : http://echogeo.revues.org/ 11539.

Le Velly R, Paturel D. 2013. Des circuits courts pour l'aide alimentaire? Hybridation de régulations dans un marché expérimental en Languedoc-Roussillon. Revue d'Etudes en Agriculture et Environnement 94(4): 443-446.

Marasas M, De Luca LC, Ullé JA. 2012. El camino de la transición agroecológica. Buenos Aires: Ediciones INTA. 
Nogueira, ME. 2013. Agricultura familiar y políticas públicas en la Argentina de los últimos años. Algunas reflexiones en torno a una relación compleja. Revista Trabajo y Sociedad 21: 49-66.

Otero J, Larrañaga G, Hang G. 2011. El invernáculo y la organización del trabajo en explotaciones familiares horticolas del cinturón verde de La Plata. Bernal, Argentina: VIII Jornadas de Investigación y debate en el agro argentino, Universidad Nacional de Quilmes.

Otero J, Larrañaga G, Hang G. 2013. La organización del trabajo en la horticultura familiar de La Plata (Argentina). Revista de la Facultad de Agronomía 112(2): 79-90.

Seba N, Tablada ML, Barbosa L, Moreira EF, Margiotta E. 2014. Estrategias de Comercialización de pequeños productores de Florencio Varela. De la quinta a la mesa. Jornadas "La viabilidad de los 'inviables'. Estudios, debates y experiencias sobre formas de producción alternativas al modelo concentrador en el agro", Universidad Nacional de Quilmes. Quilmes, Argentina, November $12-14$.

Sevilla Guzmán E, Soler Montiel M. 2009. Del desarrollo rural a la agroecología. Hacia un cambio de paradigma. Documentación Social. Revista de Estudios Sociales y Sociología Aplicada 155: 23-39.

Souza Casadinho J. 2014. La agroecología: bases científicas, historia local y estrategias productivas en la construcción de un espacio de desarrollo integral, ético y humano. In : Hernández V, Goulet F, Magda D, Girard N, eds. La agroecología en Argentina y en Francia: miradas cruzadas. Buenos Aires: Ediciones INTA, pp. 13-29.

Cite this article as: Parodi G. 2018. Agroecological transition and reconfiguration of horticultural work among family farmers in Buenos Aires, Argentina. Cah. Agric. 27: 35003. 